\title{
Trophic dynamics in antarctic benthic communities. I. In situ ingestion of microalgae by Foraminifera and metazoan meiofauna
}

\author{
Richard B. Rivkin', Ted E. DeLaca² \\ ${ }^{1}$ Horn Point Environmental Laboratories, University of Maryland, Cambridge, Maryland 21613, USA \\ ${ }^{2}$ Division of Polar Programs, National Science Foundation, Washington, DC 20550, USA
}

\begin{abstract}
Benthic microalgal production and the ingestion and subsequent metabolism of algal carbon by Foraminifera and several metazoan meiofauna were measured in situ in McMurdo Sound, Antarctica. The benthic microalgal community was dominated by the diatom Amphora antarctica. Microalgal biomass and production were $15 \pm 4.8 \mathrm{mg} \mathrm{chl} \mathrm{a} \mathrm{m} \mathrm{m}^{-2}$ (mean $\pm \mathrm{SD}$ ) and $6.0 \pm 1.9 \mathrm{mg} \mathrm{C}$ $\mathrm{m}^{-2} \mathrm{~d}^{-1}$, respectively. Weight-specific ingestion rates of microalgae by the foraminifers Astrammina rara and Astrorhiza sp. were ca 2.5 to $3.5 \mathrm{ng} \mathrm{C} \mathrm{mg} \mathrm{wet} \mathrm{wt}{ }^{-1} \mathrm{~d}^{-1}$; these rates were 2 to 3 times lower than those of the burrowing anemone Edwardsia meridionalas, small polychaetes and clams. All the meiofauna examined appeared to biosynthesize new cellular material from the ingested algal carbon. The patterns and rates of polymer synthesis differed significantly for the protozoan and metazoan meiofauna: Foraminifera synthesized 2 to 5 times more protein and 3 to 5 times less lipid than metazoans. The different patterns of polymer synthesis of the meiofauna likely reflect differences in prey preference, metabolic rates, and the pathways and rates of digestion of the ingested prey. This study suggests that there may be differences in the patterns of metabolism and trophic status of cooccurring meiofauna.
\end{abstract}

\section{INTRODUCTION}

Foraminifera are ubiquitous in marine benthic environments, including the deep sea and polar oceans. The total test-free biomass of Foraminifera in the deep sea can be greater than all other taxa combined (Hessler 1974, Smith et al. 1978, Bernstein \& Meador 1979, Snider et al. 1984). In McMurdo Sound, Antarctica, Foraminifera are conspicuous components of the soft bottom meiofaunal community (Dell 1972, DeLaca et al. 1980, DeLaca 1986a, b, DeLaca \& Bernhard unpubl.). They can attain large sizes $(\geq 38 \mathrm{~mm}$; DeLaca et al. 1980) and comprise a significant proportion of the meiofaunal community (Dayton \& Oliver 1977, DeLaca et al. 1980, Bernhard 1987). Despite their high abundance, the trophic position and the concomitant energy and material flux through Foraminifera is largely unknown (DeLaca 1982). Here we examine the in situ rates of ingestion and patterns of assimilation of naturally occurring benthic microalgae by several large species of antarctic foraminifers and associated meiofaunal metazoans.

Particle ingestion and nutrient assimilation by benthic Foraminifera has been measured in the laboratory (Lee et al. 1966, Lee 1980) and for a few temperate salt marsh species in the field (Lee \& Muller 1973). Foraminifera can ingest diverse prey, however, some species show prey selectivity (Boltovskoy \& Wright 1976, Lee et al. 1988): for example, in the laboratory Foraminifera readily consumed several species of small pennate diatoms, unicellular green algae and several species of bacteria, whereas other species of algae and bacteria and cyanobacteria, yeast, dinoflagellates and chrysophytes were either not ingested or were ingested less readily (Lee et al. 1966, 1988, Lee 1974). Furthermore, some larger species of agglutinated Foraminifera can capture and consume metazoan prey including copepods and cumaceans (Winter 1907, Christiansen 1971).

Recent laboratory investigations of benthic Foraminifera from the Ross Sea, Antarctica show them to ingest diatoms and bacteria and assimilate dissolved organic carbon (DOC) (DeLaca et al. 1980, 1981, DeLaca 1982, Alexander \& DeLaca 1987, DeLaca unpubl.). Although these results suggest that Foraminifera are potentially important to the trophic 
dynamics of shallow-water antarctic food-webs (Delaca et al. 1980, Bowser et al. 1986, DeLaca 1986a, b, Alexander \& DeLaca 1987), studies of the in situ rates and patterns of ingestion and growth are lacking. For a substrate to support growth, it must be metabolized and used for the biosynthesis of new cellular material. Thus, the measurement of ingestion or assimilation of a particulate or dissolved substrate alone is insufficient to evaluate whether that substrate is used for growth. For organisms, such as Foraminifera, where the techniques are not available to measure the growth in situ (for review see DeLaca 1986b), an alternative approach is necessary. The research presented here examined the in situ rates of ingestion of microalgae and the subsequent patterns of metabolism and polymer biosynthesis by benthic Foraminifera and associated meiofauna.

\section{METHODS}

Samples were collected in mid-December 1984 from Explorers Cove, an embayment of New Harbor on the western side of McMurdo Sound (DeLaca 1982). Using SCUBA, replicate $6.5 \mathrm{~cm}$ diameter cores were collected in diatom-rich sediments at ca $20 \mathrm{~m}$. This sampling protocol did not disturb the superficial sediment layer. Experiments were conducted within $2 \mathrm{~h}$ of collection of cores. Niskin bottles (5 l) were deployed through holes in the ice and samples were collected at $4 \mathrm{~m}$ intervals between the base of the ice and $20 \mathrm{~m}$. Incident and downwelling light (photosynthetically active radiation between 400 and $700 \mathrm{~nm}$ ) was measured with a quantum photometer (Li Cor Lambda Model LI-185B) equipped with surface (Model LI-190SB) and submarine (Model LI-192) sensors, respectively.

Radiolabelling experiments. Replicate $(n=6)$ cores were inoculated with $\mathrm{NaH}^{14} \mathrm{CO}_{3}$ to a final activity of ca $1 \mathrm{\mu Ci} \mathrm{m} l^{-1}$ in the overlying water and incubated in situ at the collection site. At ca 12 and $24 \mathrm{~h}$, cores were harvested and four $3.5 \mathrm{~cm}^{2}$ subsamples were taken from each core. The subsamples from each core were pooled, suspended in $10 \mathrm{ml}$ of filtered seawater and duplicate aliquots from each were (1) preserved in $2 \%$ buffered formalin for the identification and enumeration of microalgal species; (2) filtered onto Whatman GF/F glass-fiber filters and extracted in $90 \%$ acetone to fluorometrically determine chlorophyll a (Teitjen 1968); and (3) filtered onto GF/F glass-fiber filters to measure ${ }^{14} \mathrm{C}$ incorporation by the benthic microalgal community. Filters were digested with $0.2 \mathrm{~N}$ perchloric acid for 24 to $48 \mathrm{~h}$ to solubilize cellular material and to convert residual ${ }^{14} \mathrm{C}$-bicarbonate to ${ }^{14} \mathrm{CO}_{2}$ (Rivkin et al. 1989). The incorporation of ${ }^{14} \mathrm{C}$ and the chl a content of the dominant species were determined from separate aliquots using the single-species technique (Rivkin \& Seliger 1981, Rivkin \& Putt 1987).

After the microalgae were sub-sampled, the overlying water was removed and the core was extruded. Foraminifera and selected metazoan meiofauna isolated from the upper 2 to $3 \mathrm{~cm}$ of the core were washed by transferring through 5 serial washes of $0.2 \mu$ m membrane filtered, ambient temperature seawater (DeLaca 1986b). The sarcodes of Foraminifera were dissected from their tests and the wet weights of sarcodes and meiofauna were determined with a Cahn electrobalance (Model 28). Sarcodes and meiofaunal metazoans were digested in $2.0 \mathrm{~N} \mathrm{NaOH}$ for $24 \mathrm{~h}$ prior to counting of radioactivity. Examination of samples confirmed that the sarcodes and metazoan tissue were solubilized by this treatment.

${ }^{14}$ Carbon accumulated by microalgae and meiofauna in killed (cores incubated with $1 \%$ final concentration $\mathrm{HgCl}_{2}$ ) and darkened controls was negligible. This implies that abiotic uptake of carbon by microalgae or meiofauna did not occur and that the meiofauna did not directly assimilate inorganic carbon (Montagna 1983, Montagna \& Bauer 1988).

Polymer synthesis. The pattern of synthesis of polymers were determined for the microalgal community, the dominant algal species and individual meiofauna. After incubating in situ for ca 12 and $24 \mathrm{~h}$, the radioactive carbon incorporation into lipids, low molecular weight compounds (LMW), polysaccharides and proteins was measured by serial solvent extraction as described by Roberts et al. (1955) and Morris et al. (1974) as modified by Rivkin (1985). Specific polymer classes were extracted based on their relative solubilities in different solvents (Hitchcock 1983, Rivkin 1985), thus macromolecules were separated into functionally rather than metabolically defined classes of compounds. Lipids and LMW compounds were extracted into the chloroform and methanol-water layers, respectively, with the chloroform-methanol-water solvent system (Bligh \& Dyer 1959). Polysaccharides were solubilized by heating $5 \%$ trichloroacetic acid (TCA) at 95 to $100^{\circ} \mathrm{C}$ for $60 \mathrm{~min}$. Proteins remained in the insoluble residue (however see Smucker \& Dawson 1986). The sum of the radioactivity in the individual solvent fractions was 83 to $115 \%$ of the activity in the unextracted samples. To facilitate the comparison of labelling patterns among the different organisms (microalgae, protozoans and metazoans) and incubation times, we presented the data as percent incorporation. This presentation allows the patterns of polymer synthesis and allocation to be compared despite differences in the net ${ }^{14} \mathrm{C}$-uptake rates. The percent incorporation in each fraction (representing different polymer classes) was:

$$
\% \text { Incorp }=\frac{100 \times(\mathrm{dpm} \text { in the polymer fraction })}{\text { Sum of the } \mathrm{dpm} \text { in all fractions }}
$$


Caution should be exercised in equating an increased percent incorporation with an increased net synthesis. When comparing different experimental conditions, incubation times or organisms, an increase in the percent ${ }^{14} \mathrm{C}$ incorporation into a polymer fraction can be interpreted as an increase in the rate of polymer synthesis only when the product of the percent incorporation and the total ${ }^{14} \mathrm{C}$ uptake is higher (see Table 2).

In situ planktonic production. Replicate $(n=3) 11$ samples were collected onto Whatman GF/F filters for the fluorometric assay of chlorophyll a (Rivkin et al. 1989). Daily primary production was measured during $24 \mathrm{~h}$ in situ incubations as previously described by Rivkin et al. (1989). Water samples were inoculated with ca $0.5 \mu \mathrm{Ci} \mathrm{ml} l^{-1}$ of $\mathrm{NaH}^{14} \mathrm{CO}_{3}$ and replicate (3 light and 1 dark) $1 \mathrm{l}$ bottles were incubated at 5 depths between the base of the sea-ice and the $20 \mathrm{~m}$ bottom. An additional incubation bottle was lowered to $20 \mathrm{~m}$ and immediately retrieved. The carbon fixed during transit to depth was subtracted from all in situ incubations.

Radioactivity counting. Radioactivity was counted using a Beckman liquid scintillation spectrometer (Model LS-6800) with Biofluor as the scintillant. All counts were corrected for quench from sediments, oxidizing agents and solvents by the external standard method and for background. Counting efficiency was 70 to $88 \%$ and counting times were adjusted to provide a standard error of the count of $<8 \%$

Population structure. The abundances of Foraminifera and meiofaunal metazoans were determined by randomly placing $100 \mathrm{~cm}^{2}$ (10 cm square) cores in to the sediment. The locations of the cores relative to one another, to depth and to local topographic and biological features were noted. The upper $2 \mathrm{~cm}$ of the sediment was washed through nested sieves $(5.0,1.0,0.5$ and $0.067 \mathrm{~mm}$ apertures) and the Foraminifera and selected species of meiofaunal metazoans retained on the $0.5 \mathrm{~mm}$ and $0.067 \mathrm{~mm}$ sieves were identified and counted immediately. The abundance of the larger arborescent foraminifera were counted in situ in $400 \mathrm{~cm}^{-2}$ quadrants (DeLaca et al. 1980).

\section{RESULTS AND DISCUSSION}

\section{Microalgal production and biomass}

During the austral summer, benthic diatoms grow to a maximum depth of ca $30 \mathrm{~m}$ in Explorers Cove. Chlorophyll a concentrations and daily production in the sediments were $15.0 \pm 4.8 \mathrm{mg} \mathrm{chl} \mathrm{a} \mathrm{m} \mathrm{m}^{-2}$ (mean \pm $\mathrm{SD}, \mathrm{n}=18$ ) and $6.0 \pm 1.9 \mathrm{mg} \mathrm{C} \mathrm{m} \mathrm{Cd}^{-1}$ (mean $\pm \mathrm{SD}$, $\mathrm{n}=18$ ), respectively (Table 1 ). The microalgal community was dominated by Amphora antarctica and there were $6.0 \pm 0.75 \times 10^{7} \mathrm{~A}$. antarctica $\mathrm{m}^{-2}$. Other
Table 1. Microalgal biomass ( $\mathrm{mg} \mathrm{chl}$ a $\mathrm{m}^{-2}$ ) and primary production ( $\left.\mathrm{mg} \mathrm{C} \mathrm{m}^{-2} \mathrm{~d}^{-1}\right)$ in the benthos $(20 \mathrm{~m}$ ) and plankton of Explorers Cove, New Harbor during mid-December

\begin{tabular}{|ccc|}
\cline { 3 - 3 } & Benthos & Plankton \\
\hline Chlorophyll $a$ & & \\
Range & $11-35$ & $0.22-1.3$ \\
Mean $\pm \mathrm{SD}$ & $15 \pm 4.8$ & $0.69 \pm 0.26$ \\
Production & & \\
Range & $3.4-8.2$ & $0.30-0.45$ \\
Mean $\pm \mathrm{SD}$ & $6.0 \pm 1.9$ & $0.37 \pm 0.10$ \\
\hline
\end{tabular}

taxa present in lower abundances were Trachyneas aspera, Amphiprora kufferathii, Fragilariopsis sp. and Nitzschia sp. A. antarctica had $180 \pm 22 \mathrm{pg} \mathrm{chl} \mathrm{a} \mathrm{cell-1}$ (mean $\pm \mathrm{SD}, \mathrm{n}=5$ ) and a daily production of $76 \pm$ $11 \mathrm{pg} \mathrm{C}$ cell ${ }^{-1} \mathrm{~d}^{-1}$ (mean $\pm \mathrm{SD}, \mathrm{n}=18$ ): based upon the standing stock of chlorophyll $a$ and rate of primary production of the microalgal community and the species-specific biomass and productivity of $A$. antarctica, this one taxa contributed ca 70 to $75 \%$ of the chlorophyll $a$ and primary production in the sediments.

During these experiments, mid-day irradiances incident at surface of the sea-ice and at $20 \mathrm{~m}$ were 1100 to 1300 and 1 to $3 \mu \mathrm{E} \mathrm{m}^{-2} \mathrm{~s}^{-1}$, respectively. Benthic algae can adapt to very low irradiances (Palmisano et al. 1985, Rivkin \& Putt 1987). For example, carbon uptake by Amphora antarctica isolated from 18 to $20 \mathrm{~m}$ near McMurdo Station on the west side of McMurdo Sound saturated at ca $6 \mu \mathrm{E} \mathrm{m}^{-2} \mathrm{~s}^{-1}$ (Rivkin \& Putt 1987). The rates of photosynthesis and chl a cell ${ }^{-1}$ of $A$. antarctica from near McMurdo Station and New Harbor were similar.

\section{Ingestion of microalgae by meiofauna}

Since the complex sedimentary environment both constrains the behavior and influences the efficiency of prey capture of meiofauna, studies which are conducted under laboratory conditions may not accurately reflect the in situ rates and patterns of particle ingestion. In this study, the ingestion of radiolabelled algal carbon by Foraminifera and several common metazoans were measured under in situ conditions of light, temperature, and predator and prey abundance and orientation. Since the protozoa and meiofauna as well as their microalgal prey were incubated in cores to which ${ }^{14} \mathrm{C}$ was added, the radioactivity within both the algal and consumer trophic compartments increased concurrently. The rates of ingestion of ${ }^{14} \mathrm{C}$-labelled microalgae by the Foraminifera and metazoan meiofauna were determined by the 3 compartment model of Daro (1978) as modified by Roman \& Rublee (1981) and Montagna (1984). We did not 


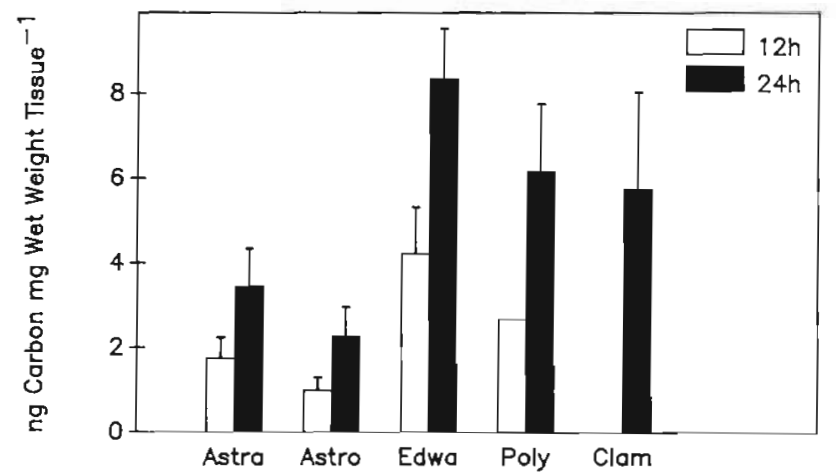

Fig. 1. Weight-specific incorporation rates of ${ }^{14} \mathrm{C}$-labelled microalgae by the Foraminifers Astrammina rara (Astra) and Astrorhiza sp. (Astro), the burrowing anemone Edwardsia meridionalas (Edwa), a small polychaete (Poly) and clam. Meiofauna were assayed after 12 and $24 \mathrm{~h}$ in situ incubations. Error bars are standard deviations $(n=5$ to 11 individuals assayed)

measure rates of respiration, excretion or the recycling of ${ }^{14} \mathrm{C}$-labelled compounds by the meiofauna. Therefore, the ingestion rates measured over the 12 to $24 \mathrm{~h}$ incubations were minimum estimates.

Weight-specific ingestion rates of the Foraminifera Astrammina rara and Astrorhiza sp. ranged from ca 2.5 to $3.5 \mathrm{ng} \mathrm{C} \mathrm{mg} \mathrm{wet} \mathrm{wt}^{-1} \mathrm{~d}^{-1}$ (Fig. 1). The rates of uptake for the burrowing anemone Edwardsia meridionalas, polychaetes and clams were 2 to 3 times greater than the Foraminifera (Fig. 1). Ingestion rates were approximately linear during the experiments. For example, the accumulation of radiolabelled algae after $24 \mathrm{~h}$ was ca twice that measured after $12 \mathrm{~h}$. The relatively uniform rate of ${ }^{14} \mathrm{C}$ accumulation suggested that the ingestion rate was not limited by prey concentration and the Foraminifera and meiofauna were not adversely affected by the experimental manipulations. Ingestion rates were also measured for 2 large arborescent Foraminifera, Notodendroides antarctikos and an as yet undescribed species within the family Notoanthoides (DeLaca unpubl.). Due to their complex morphology, their sarcodes were not dissected and weights were not determined. These Foraminifera ingested 37 \pm 4 and $33 \pm 6 \mathrm{ng} \mathrm{C}$ ind. ${ }^{-1} \mathrm{~d}^{-1}$, respectively.

\section{Polymer labelling patterns}

During this study, we concurrently measured the patterns of polymer synthesis by the microalgal assemblage (Fig. 2A), by the diatom Amphora antarctica (Fig, 2B) and by the several species of Foraminifera and metazoan meiofauna (Fig. 3). There were significant $(p=0.05)$ differences in the labelling patterns of the microalgae (Fig. 2) and the meiofauna and among the Foraminifera and the metazoans (Fig. 3).
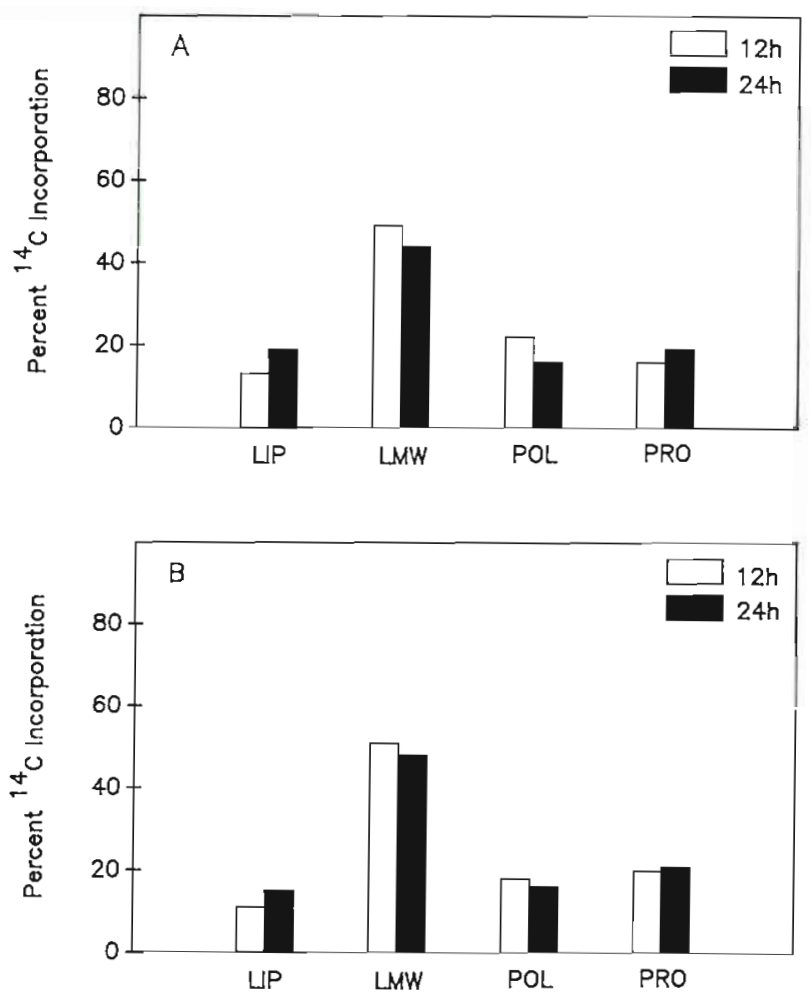

Fig. 2. Pattern of incorporation of $\mathrm{NaH}^{14} \mathrm{CO}_{3}$ into lipids (LIP), low molecular weight compounds (LMW), polysaccharides (POL), and proteins (PRO) by (A) the natural benthic microalgal assemblage and (B) Amphora sp. during 12 and $24 \mathrm{~h}$ in situ incubations

The labelling patterns of the microalgal assemblage (Fig. 2A) and Amphora antarctica (Fig. 2B) were identical. Further, there was no significant difference (Students $t$ test, $\mathrm{p}=0.05$ ) in the percentage of ${ }^{14} \mathrm{C}$ in the different polymer fractions at 12 and $24 \mathrm{~h}$ (Fig. 2). This suggests that isotopic equilibrium among the polymer pools was reached within $12 \mathrm{~h}$ (Hitchcock 1983, Smith \& Geider 1985, Rivkin 1989). Between 10 and $20 \%$ of the ${ }^{14} \mathrm{C}$ was incorporated into the lipid (LIP), polysaccharide (POL) and protein (PRO) fractions and ca $50 \%$ was incorporated into LMW compounds.

The ${ }^{14} \mathrm{C}$-labelling patterns of the Foraminifera and metazoan meiofauna differed significantly (analysis of variance [ANOVA], $p=0.05$ ) from their benthic algal prey, Labelling patterns of the algae and meiofauna would be qualitatively similar if (1) the ${ }^{14} \mathrm{C}$ were directly incorporated by epifaunal algae rather than the meiofauna (Teitjen 1971); (2) the algae in the food vacuoles of the Foraminifera or gut of the metazoan meiofauna were retained but not digested; or (3) the meiofauna digested the algae without transforming the algal polymers. The significant difference in labelling patterns of the algae and the meiofauna (Figs. 2 and 3) suggests that the Foraminifera and metazoan meiofauna 

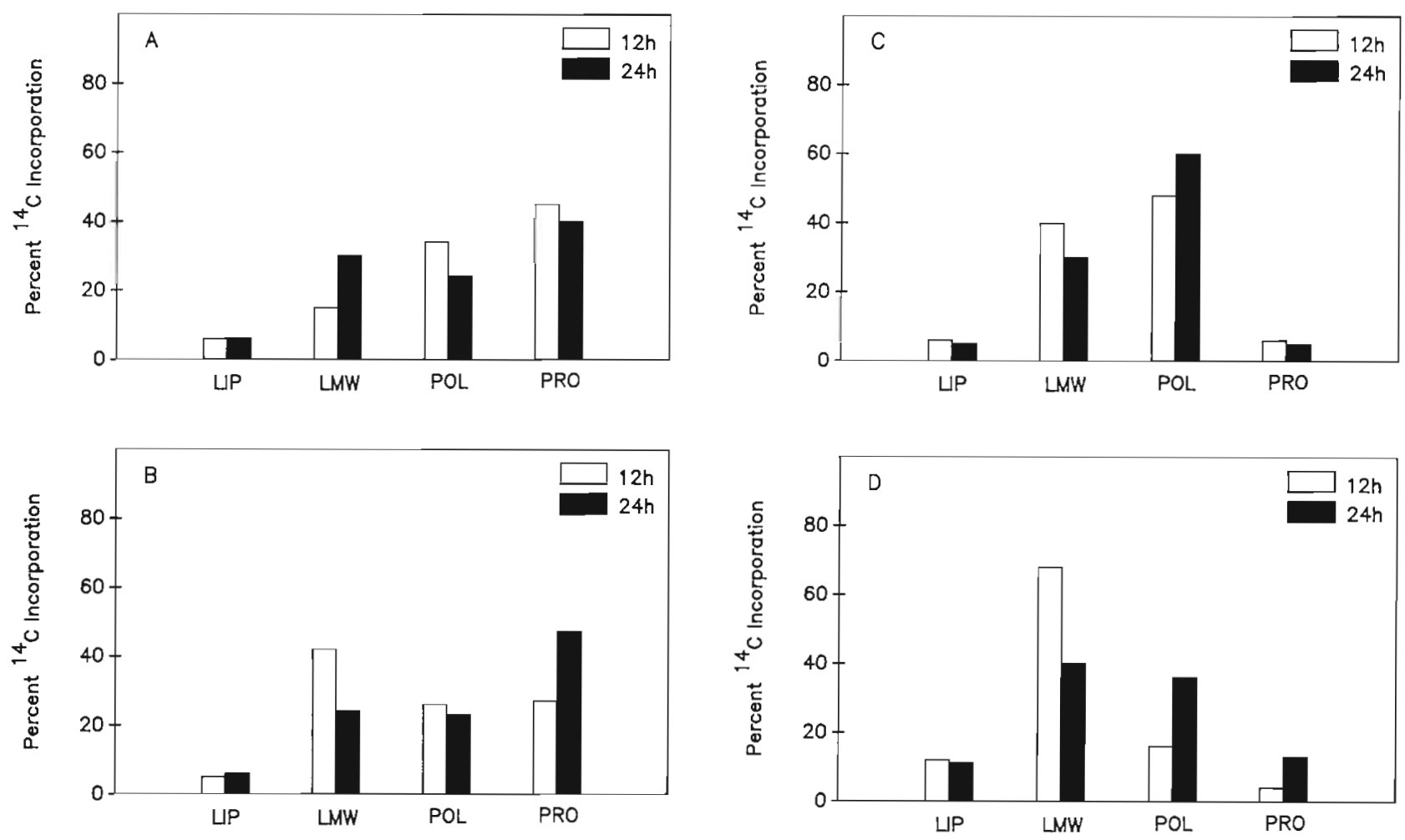

Fig. 3. Pattern of incorporation of ${ }^{14} \mathrm{C}$-labelled benthic microalgae into the lipid (LIP), low molecular weight compound (LMW), polysaccharide (POL), and protein (PRO) fractions of (A) Astrammina rara, (B) Astrorhiza sp., (C) Edwardsia meridionalas, (D) a small polychaete and (E) a clam during 12 and $24 \mathrm{~h}$ in situ incubations

metabolized the algal carbon and used it to synthesize new cellular material. In Foraminifera $<$ ca $10 \%$ of the ingested algal ${ }^{14} \mathrm{C}$-carbon was recovered from LIP, 20 to $40 \%$ was recovered from LMW compounds and POL and 30 to $50 \%$ was recovered from PRO (Fig. 3A, B). There was a reallocation of ${ }^{14} \mathrm{C}$ among polymer pools between 12 and $24 \mathrm{~h}$, however the patterns were species-specific (Fig. 3A, B). In contrast to the Foraminifera, most (80 to $90 \%$ ) of the algal ${ }^{14} \mathrm{C}$ was recovered from POL and LMW compounds and ca $10 \%$ was recovered from LIP and PRO in Edwardsia meridionalas (Fig. 3C) and the polychaete (Fig. 3D). The polychaete reallocated ${ }^{14} \mathrm{C}$ from LMW compounds to POL (Fig. 3D) during the 12 to $24 \mathrm{~h}$ interval. The ${ }^{14} \mathrm{C}$ labelling patterns for the clam was measured after $24 \mathrm{~h}$ only (Fig. 3E) and they were similar to the other metazoan.

The patterns of synthesis (i.e. the product of the

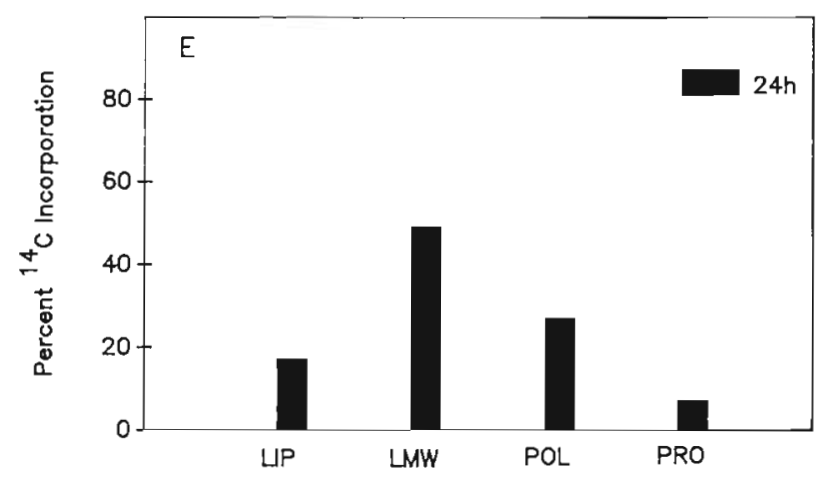

percentage ${ }^{14} \mathrm{C}$ in the polymer and the total ${ }^{14} \mathrm{Cingested}$ ), as well as the percentage incorporation of ${ }^{14} \mathrm{C}$ into the polymers, differed among the meiofauna (Table 2 , Fig. 3). The greatest difference was for PRO (Table 2). For example, the ingestion rates of algal carbon by Foraminifera were lower than the metazoans (Fig. 1) However during the same incubation interval, the Foraminifera synthesized 2 to 5 -fold more PRO and 2 to 4-fold less LIP than the metazoans (Table 2): the metazoans synthesized predominately POL and LMW compounds (Table 2).

\section{Community structure}

The rates and patterns of ingestion of microalgae were measured for meiofauna which were abundant 
Table 2. Synthesis of lipids, low molecular weight compounds (LMW), polysaccharides and proteins from radiolabelled algal prey by benthic Foraminifera and metazoan meiofauna. Synthesis calculated as the product of the percent ${ }^{14} \mathrm{C}$ incorporation into that polymer and the net carbon incorporation. Each value is the mean of 4 to 6 determinations and the coefficients of variation were 12 to $20 \%$. Data are $\mathrm{ng}$ polymer $\mathrm{C} \mathrm{mg}^{-1}$ wet wt tissue for 12 and $24 \mathrm{~h}$ incubations. ND: not determined

\begin{tabular}{|lcccccccc|}
\hline \multirow{2}{*}{ Meiofauna } & \multicolumn{2}{c}{ Lipids } & \multicolumn{2}{c}{ LMW } & \multicolumn{2}{c}{ Polysaccharides } & \multicolumn{2}{c}{ Proteins } \\
& $12 \mathrm{~h}$ & $24 \mathrm{~h}$ & $12 \mathrm{~h}$ & $24 \mathrm{~h}$ & $12 \mathrm{~h}$ & $24 \mathrm{~h}$ & $12 \mathrm{~h}$ & $24 \mathrm{~h}$ \\
\hline Astrammina rara & 0.172 & 0.206 & 1.441 & 0.234 & 0.892 & 0.789 & 0.926 & 1.612 \\
Astrorhiza sp. & 0.136 & 0.136 & 0.339 & 0.678 & 0.768 & 0.542 & 1.017 & 0.904 \\
Edwardsia meridionalas & 0.499 & 0.416 & 3.332 & 2.499 & 3.998 & 4.998 & 0.499 & 0.417 \\
Polychaete & 0.738 & 0.675 & 4.182 & 2.214 & 0.984 & 2.214 & 0.246 & 0.799 \\
Clam & $\mathrm{ND}$ & 0.972 & $\mathrm{ND}$ & 2.803 & $\mathrm{ND}$ & 1.544 & ND & 0.400 \\
\hline
\end{tabular}

and representative of the benthic soft bottom community on the west side of McMurdo Sound. The abundances measured here (Table 3 ) were similar to those reported previously. The numerical dominant meiofauna in Explorers Cove are Foraminifera, small infaunal polychaetes, clams and crustaceans (Oliver 1979, DeLaca et al. 1980, DeLaca unpubl.); the meioand small macro-epifauna is dominated by arenaceous arborescent Foraminifera (especially Notodendrodes antarctikos: DeLaca et al. 1980), various tube dwelling metazoans, and Edwardsia meridionalas (Dayton \& Oliver 1977, Oliver 1979).

\section{CONCLUSIONS}

The patterns of biomass distribution and primary production by planktonic and benthic microalgae in McMurdo Sound are temporally and spatially variable (Bunt 1964, Dayton \& Oliver 1977. Dayton et al. 1986, Rivkin \& Voytek 1987, Rivkin 1990). Primary production and the abundance of benthic infauna are reported to be significantly higher on the east side (e.g. near McMurdo Station) than the west side (i.e. New Harbor) of McMurdo Sound (Dayton \& Oliver 1977, Dayton et al. 1986, Barry 1988). The circulation patterns in the western Ross Sea and McMurdo Sound result in an advection of water with relatively high concentrations

Table 3. Abundances (mean $\pm \mathrm{SD}$; no. ind. $\mathrm{m}^{-2}$ ) of protozoan and metazoan meiofauna in Explorers Cove at the time microalgal ingestion was measured $(\mathrm{n}=$ no. of cores examined)

\begin{tabular}{|lrrr|}
\hline Meiofauna & Mean & SD & $\mathrm{n}$ \\
\hline Astrammina rara & 821 & 378 & 24 \\
Astrorhiza sp. & 129 & 155 & 24 \\
Edwardsia meridionalas & 233 & 53 & 24 \\
Polychaeta & 467 & 282 & 24 \\
Clams & 254 & 23 & 24 \\
Notodendrodes antarctikos & 97 & 56 & 12 \\
Unnamed Notoanthoides & 119 & 26 & 16 \\
\hline
\end{tabular}

of particles along the east side of the McMurdo Sound. A countercurrent of nearly particle-free water originating under the Ross Ice Shelf flows along the west side of McMurdo Sound (Dayton \& Oliver 1977, Lewis \& Perkins 1985, Barry \& Dayton 1988). Hence, allochthonous inputs of biomass to the benthos in New Harbor are very low.

Autochthonous inputs of carbon to the benthos of Explorers Cove and New Harbor are from in situ phytoplankton, ice and benthic microalgae production. Planktonic biomass and in situ planktonic production in New Harbor during the austral summer was 0.30

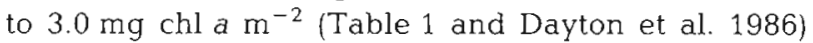
and $0.37 \mathrm{mg} \mathrm{C} \mathrm{m} \mathrm{m}^{-2} \mathrm{~d}^{-1}$ (Table 1 ), respectively; this was up to 3 or 4 orders of magnitude lower than the biomass and production on the west side of McMurdo Sound (for review see Rivkin 1990). Ice algal biomass and production can be high near McMurdo Station (Palmisano \& Sullivan 1983, Grossi et al. 1987), however ice algal communities in Explorers Cove have not been studied. Ice algal growth is irradiance limited (Grossi et al. 1987) and in Explorers Cove, where sea-ice typically persists for several years (DeLaca unpubl.), the irradiances at the ice-seawater interface are much lower than at the base of the 1-yr ice near McMurdo Station. This fundamental difference in the characteristics of the sea-ice on the east and west sides of McMurdo Sound may result in much lower ice algal biomass and production in Explorers Cove than on the east side of McMurdo Sound. During the early austral summer, the benthic microalgal biomass and production was 5 to 20 times greater than planktonic biomass and production (Table 1). Thus, benthic microalgal production may represent the primary input of autochthonous carbon to the benthos in New Harbor.

The benthic microalgal biomass measured here was similar to the 18 to $145 \mathrm{mg} \mathrm{chl} \mathrm{a} \mathrm{m} \mathrm{m}^{-2}$ reported for New Harbor during November and December 1975 by Dayton et al. (1986) and was significantly lower than the chlorophyll a from similar depths near 
McMurdo Station (Dayton et al. 1986). Benthic production measured in Explorers Cove (Table 1), however, was 10 to 20 times lower than was reported in 1975 (2.4 to $62 \mathrm{mg} \mathrm{C} \mathrm{m}{ }^{-2} \mathrm{~d}^{-1}$; Dayton et al. 1986). The ice conditions in 1975 and 1984 differed and may have resulted in higher downwelling irradiances during 1975 (Dayton et al. 1986, Dayton pers. comm.). Alternatively, production measurements in 1975, which were based on short mid-day incubations of shaken sediment, may have disrupted the habitat of the benthic algae and overestimated daily in situ production. The rates of production we report for New Harbor were based on $24 \mathrm{~h}$ in situ incubations of undisturbed cores and thus accurately represent daily production.

The trophic dynamics of the meiobenthic and microbial communities are closely coupled (Coull 1973, Fenchel 1978, Gerlach 1978, Teitjen 1980). Benthic algae and bacteria are ingested by polar and temperate protozoan and metazoan meiofauna (Teitjen 1980, Rieper \& Flotow 1981, Admiraal et al. 1983, Montagna 1984, Alexander \& DeLaca 1987, Lee et al. 1988 and references therein). In this study, benthic microalgal production and the ingestion and subsequent metabolism of algal carbon by a natural meiofaunal community were measured under in situ conditions of light, temperature and predator and prey abundance. Hence, the results of this study can be extrapolated to the natural environment. These observed in situ patterns of polymer synthesis suggest that the ingested benthic microalgae were used for the biosynthesis of complex polymers and for growth by meiofauna. There were significant differences in the weight-specific rates of ingestion and the patterns of metabolism among the meiofauna. The rates of ingestion by Foraminifera were lower than the other meiofauna examined. However, Foraminifera synthesized 2 to 5 times more protein and 3 to 5 times less lipid than that of the metazoan meiofauna (Table 2). The differences in the patterns of polymer synthesis of the co-occurring meiofauna may reflect differences in prey selectivity and preference, in metabolic and growth rates, or in pathways and rates of digestion of the ingested prey. The district patterns of polymer synthesis suggest that the chemical composition, the nutritional value and trophic status of the different meiofaunal taxa may also differ.

Acknowledgements. We thanks Drs P. A. Anderson, M. R. Anderson and Mr D. E. Gustafson for comments early drafts of the manuscript, K. M. Smith for graphics, and J. Bernhard, K. Miller and W. Stockton for assistance with the SCUBA diving. The staff of the National Science Foundation and the ITT Antarctic Services provided logistic support in the Antarctic. This research was supported by NSF grants DPP 8314607 . 8520278 and OCE 8516214 to R.B.R. and DPP 8305475 to T.E.D. University of Maryland, Center for Environmental and Estuarine Studies contribution no. 2118.

\section{LITERATURE CITED}

Admiraal, W., Bouwman, L. A., Hoekstra, L., Romeyn, K. (1983). Qualitative and quantitative interactions between microphytobenthos and herbivorous meiofauna on a brackish intertidal mudflat. Int. Revue ges. Hydrobiol. 68: 175-191

Alexander, S. P., DeLaca, T. E. (1987). Feeding adaptations of the foraminiferan Cibicides refulgens living epizoically and parasitically on the antarctic scallop Adamussium coibecki. Biol. Bull. mar. biol. Lab., Woods Hole 173: 136-159

Barry, J. P. (1988). Hydrographic patterns in McMurdo Sound, Antarctica and their relationship to local benthic communities. Polar Biol. 8: 377-391

Barry, J. P., Dayton, P. K. (1988). Current patterns in McMurdo Sound, Antarctica and their relationship to local biotic communities. Polar Biol. 8: 367-376

Bernhard, J. M. (1987). Foraminiferal biotopes in Explorers Cove, McMurdo Sound, Antarctica. J. foraml Res. 17: 286-297

Bernstein, B. B., Meador, J. P. (1979). Temporal persistence of biological patch structure in an abyssal benthic community. Mar. Biol. 51: 179-183

Bligh, E. E., Dyer, W. J. (1959). A rapid method of total lipid extraction and purification. Can. J. Biochem. Physiol. 37 : 911-917

Boltovskoy, E., Wright, R. (1976). Recent foraminifera. W. Junk, Publishers, The Hague

Bowser, S. S., DeLaca, T E., Reider, C. L. (1986). Novel extracellular matrix and microtubule cables associated with pseudopodia of Astrammina rara, a carnivorous antarctic foraminifer. J. Ultrastruct. Res. 94: 149-160

Bunt, J. S. (1964). Primary productivity under sea ice in Antarctic water. Antarctic Res. Ser 1: 13-31

Christiansen, B. (1971). Notes of the biology of foraminifera Vie Milieu (Suppl.) 22: 465-478

Coull, B. C. (1973). Estuarine meiofauna: a review: trophic relationships and microbial interactions. In: Stevenson, L. H., Colwell, R. R. (eds.) Estuarine microbial ecology. University of South Carolina Press, Columbia, p. 499-511

Daro, M. H. (1978). A simplified ${ }^{14} \mathrm{C}$ method for grazing measurements on natural planktonic populations. Helgoländer wiss. Meeresunters. 13: 241-248

Dayton, P. K., Oliver, J. S. (1977). Antarctic soft bottom benthos in oligotrophic and eutrophic environments. Science 197: 55-58

Dayton, P. K., Watson, D., Palmisano, A., Barry, J. P., Oliver, J, S., Rivera, D. (1986). Distribution patterns of benthic microalgal standing stock at McMurdo Sound, Antarctica. Polar Biol. 6: 207-213

Delaca, T. E. (1982). Use of dissolved amino acids by the foraminifer Notodendrodes antarctikos. Am. Zool. 22: $683-690$

DeLaca, T. E. (1986a). Determination of benthic rhizopod biomass using ATP analyses. J. foraml Res. 16: 285-292

Delaca, T. E. (1986b). The morphology and ecology of Astrammina rara. J. foraml Res. 16: 216-223

DeLaca, T. E., Karl, D. M., Lipps, J. H. (1981). Direct use of dissolved organic carbon by agglutinated benthic foraminifera. Nature, Lond. 289: 287-289

DeLaca, T. E., Lipps, J. H., Hessler, R. R. (1980). The morphology and ecology of a large agglutinated antarctic foraminifer (Textulariina: Notodendrodidae nov.). J. Linn. Soc. (Zool.) 69: 205-224

Dell, R. K. (1972). Antarctic benthos. Adv, mar. Biol, 10: 1-216

Fenchel, T. M. (1978). The ecology of micro- and meiobenthos. A. Rev. Ecol. Syst. 9: 99-121 
Gerlach, S. A. (1978). Food chain relationships in subtidal silty sand marine sediments and the role of meiofauna in stimulating bacterial productivity. Oecologia (Berl.) 33: $55-59$

Grossi, S. M. Kottmeier, S. K., Moe, R. L., Taylor, G. T., Sullivan, C. W. (1987). Sea ice microbial communities. VI Growth and primary production in bottom ice under graded snow cover. Mar. Ecol. Prog. Ser. 35: 153-164

Hessler, R. R. (1974). The structure of deep benthic communities from central oceanic waters. In: Miller, C. B. (ed.) The biology of the oceanic Pacific. Oregon State Univ. Press, Corvallis, p. 79-93

Hitchcock, G. L. (1983). Photosynthate partitioning in cultured marine phytoplankton. I. Dinoflagellates. J. exp. mar. Biol. Ecol. 69: 21-36

Lee, J. J. (1974). Towards understanding the niche of Foraminifera. In: Hedley, R. H., Adams, C. G. (eds.) Foraminifera. Academic Press, New York, p. 207-260

Lee, J. J. (1980). Nutrition and physiology of the foraminifera. Biochem. Physiol. Protozoa 3: 43-66

Lee, J. J., Erez, J., Juile, B. T., Lagziel, A., Burgos, S. (1988). Feeding rates of two species of larger foraminifera Amphistegina lobifera and Amphisorus hemprichii, from the Gulf of Eilat (Red Sea). Symbioses 5: 61-102

Lee, J. J., McEnery, M., Pierce, Freudenthal, H. D., Muller, W. A. (1966). Tracer experiments in feeding littoral foraminifera. Protozoology 13: 659-670

Lee, J. J., Muller, W. A. (1973). Trophic dynamics and niches of salt marsh Foraminifera. Am. Zool. 13: 215-223

Lewis, E. L., Perkins, R. G. (1985). The winter oceanography of McMurdo Sound, Antarctica. Antarctic Res. Ser. 43: 145-166

Montagna, P. A. (1983). Live controls for radioisotope tracer food chain experiments using meiofauna. Mar Ecol. Prog. Ser. 12: 43-46

Montagna, P. A. (1984). In-situ measurement of meiobenthic grazing rates on sediment bacteria and edaphic diatoms. Mar. Ecol. Prog. Ser, 18: 119-130

Montagna, P. A., Bauer, J. E. (1988). Partitioning radiolabelled thymidine uptake by bacteria and meiofauna using metabolic blocks and poisons in benthic feeding studies. Mar. Biol. 98: 101-110

Morris, I., Glover, H. E., Yentsch, C. S. (1974). Products of photosynthesis by marine phytoplankton: the effect of environmental factors on the relative rates of protein synthesis. Mar. Biol. 27: 1-9

Oliver, J. S. (1979). Processes affecting the organization of marine soft-bottom communities in Monterey Bay, California and McMurdo Sound, Antarctica. Ph. D. dissertation, University of California, San Diego

Palmisano, A. C., SooHoo, J. B., White, D. C., Smith, G. A., Stanton, G. R., Burckle, L. H. (1985). Shade adapted benthic diatoms beneath Antarctic sea ice. J. Phycol. 21, 664-667

Palmisano, A. C., Sullivan, C. W. (1983). Sea ice microbial communities (SIMCO). 1. Distribution, abundance and primary production of ice microalgae in McMurdo Sound, Antarctica in 1980. Polar Biol. 2: 171-177

This article was presented by Professor K. R. Tenore, Solomons, Maryland, USA
Rieper, M., Flotow, C. (1981). Feeding experiments with bacteria, ciliates and harpacticoid copepods. Kieler Meeresforsch. (Sonderh.) 5: 370-375

Rivkin, R. B. (1985). Carbon-14 labelling patterns of individual marine phytoplankton from natural populations. Mar. Biol. 89: $135-142$

Rivkin, R. B. (1989). Influence of irradiance and spectral quality on the carbon metabolism of phytoplankton. 1. Photosynthesis, chemical composition and growth. Mar. Ecol. Prog. Ser. 55: 291-304

Rivkin, R. B. (1990). Seasonal patterns of planktonic production in McMurdo Sound, Antarctica. Am. Zool. (in press)

Rivkin, R. B., Putt, M. (1987). Photosynthesis and cell division by antarctic microalgae: comparison of benthic, planktonic and ice algae. J. Phycol. 23: 223-229

Rivkin, R. B., Seliger, H. H. (1981). Liquid scintillation counting for ${ }^{14} \mathrm{C}$ uptake of single algal cells isolated from natural samples. Limnol. Oceanogr. 26: 780-785

Rivkin, R. B., Putt, M., Alexander, S. P., Meritt, D., Gaudet, L. (1989). Biomass and production in polar planktonic and sea ice microbial communities: a comparative study. Mar. Biol. 101. 273-283

Rivkin, R. B., Voytek, M. A. (1987). Photoadaptations of photosynthesis and carbon metabolism by phytoplankton from McMurdo Sound, Antarctica. 1. Species-specific and community responses to reduced irradiances Limnol Oceanogr. 32: 249-259

Roberts, R. B., Cowie, D. B., Abelson, P. H., Bolton, E. T. Britten, R. J. (1955). Studies of biosynthesis in Escherichia coli. Publs Camegie Instn 607: 1-521

Roman, M. R., Rublee, P. A. (1981). A method to determine in situ zooplankton grazing rates on natural particle assemblages. Mar. Biol. 65: 303-309

Smith, K. L., White, G. A., Laver, M. B., Haugness, J. A. (1978) Nutrient exchange and oxygen consumption by deep-sea benthic communities: preliminary in situ measurements. Limnol. Oceanogr. 23: 997-1005

Smith, R. E. H., Geider, R. J. (1985). Kinetics of intracellular carbon allocation in a marine diatom. J. exp. mar. Biol. Ecol. 93: 191-210

Smucker, R. A., Dawson, R. (1986). Products of photosynthesis by marine phytoplankton: chitin in TCA 'protein' precipitates. J. exp. mar. Biol. Ecol. 104: 143-152

Snider, L. J., Burnett, R. R., Hessler, R. R. (1984). The composition and distribution of meiofauna and nanobiota in a central North Pacific deep-sea area: Deep Sea Res. 31: $1225-1249$

Tietjen, J. H. (1968). Chlorophyl and pheopigments in estuarine sediments. Limnol. Oceanogr 13: 189-192

Tietjen, J. H. (1971). Pennate diatoms as ectocommensals of free-living marine nematodes. Oecologia (Berl.) 8: $135-138$

Tietjen, J. H. (1980). Microbial-meiofaunal interrelationships: a review. Microbiology 335-383

Winter, F. W. (1907). Zur Kenntnis der Thalamophonen. I. Untersuchungen über Peneroplis pertusus (Forskal). Arch. Protistenk, 10: 1-113

Manuscript first received. August 25, 1989

Revised version accepted: March 9, 1990 